\title{
ПСИХОЛОГО-ПЕДАГОГІЧНІ АСПЕКТИ ІНТЕНСИФІКАЦІЇ НАВЧАЛЬНОЇ ДІЯЛЬНОСТІ СТУДЕНТІВ
}

Стаття присвячена визначенню сутності інтенсифікації навчального процесу та висвітленню психолого-педагогічних аспектів інтенсифікації навчальної діяльності студентів у вищому начальному закладі. Запропоновані шляхи вдосконалення змісту навчального матеріалу і методів навчання.

Ключові слова: екстенсивний підхі, інтенсифікація, процес навчання, інтенсифікація навчання, активізаџія навчання.

Статья посвящена определению сущности интенсификации учебного прочесса и освещению психолого-педагогических аспектов интенсификации учебной деятельности студентов в высшем учебном заведении. Предложены пути совершенствования содержания учебного материала и методов обучения.

Ключевые слова: экстенсивный подход, интенсификаџия, прочеесс обучения, интенсификаџия обучения, активизаџия обучения.

The article is devoted to the definition of the essence of the intensification of the educational process and the coverage of psychological and pedagogical aspects of the intensification of students' learning activities in a higher educational establishment. The ways of improving the content of educational material and teaching methods are suggested.

Key words: extensive approach, intensification, educational process, intensification of education, activation of education.

Нині ми маємо змогу спостерігати за стрімким розвитком суспільства і тому повинні до нього пристосовуватися. У Свропі досвід розвитку країн свідчить про те, що чим вищий освітній рівень населення, тим потужніша держава, тим краще живе іiі народ. Тому до випускників університетів, академій чи інститутів висуваються високі вимоги. 3 огляду на це у вищих навчальних закладах було впроваджено Болонський процес, водночас важливим елементом у покращенні освіти в Україні, досягненні європейського рівня слід уважати також інтенсифікацію навчально-пізнавальної діяльності, спрямованої на розкриття творчого потенціалу студентів, заохочення їх до знань, активної участі в навчальному процесі.

Окреслена проблема не $\epsilon$ новою, проте залишається актуальною. Активізація навчальної діяльності прямо пропорційно залежить від викладача. Саме він повинен докласти якнайбільше зусиль, щоб досягти позитивного результату, тобто зацікавити студентів у навчальному процесі. Для цього потрібна не тільки мотивація, але і якість знань, що відіграє важливу роль, а також подальші розбудова й розширення обсягів отриманої інформації, іiі практичне застосування, вміння студентів самостійно працювати. Виклакладач має визначити оптимальні варіанти для подання знань, застосувати такі методи, форми і засоби навчання, які би сприяли розвитку творчості, активності, збільшували інтерес студентів до навчальної діяльності. Щоб керувати спілкуванням, викладач повинен оволодіти засобами налагодження та підтримання контакту, навчати студентів встановлення контакту й певних комунікативних стереотипів.

Підвищенню ефективності інтелектуальної діяльності людини присвячено праці багатьох учених (В. Альохін, В. Ганзен, Б. Кедров, В. Ляудіс, В. Моляко). Проблему інтенсифікації навчання в цілому вивчали такі вітчизняні та зарубіжні дослідники, як В. Андреєв, Ю. Бабанський, В. Беспалько, 3. Васильєва, О. Гусевська, І. Лернер, В. Лихолєтов, Г. Лозанов, О. Матюшкін, М. Махмутов, Н. Ничкало, П. Підкасистий, Н. Половникова, С. Сисоєва, М. Скаткін, В. Сластьонін та ін. Остнаннім часом усе більше уваги у світовому освітньому просторі приділяється інтенсифікації та оптимізації навчального процесу, що зумовлено необхідністю управління знаннями (менеджментом знань) та інноваційними методами їх візуалізації (Т. Б’юзан, О. Ігнатьєва, В. Шаталов, Р. Буркхард, Г. Джудельман, М. Епплер).

Вивчення психолого-педагогічної літератури, яка стосується теми статті, дає змогу зробити висновок, що на сьогодні залишаються недостатньо вивченими та розробленими педагогічні умови інтенсифікації навчання.

Mета статmi - визначити сутність інтенсифікації навчального процесу, висвітлити психологопедагогічні аспекти інтенсифікації навчальної діяльності студентів у вищому начальному закладі.

Процеси інтеграції в сучасному світі охоплюють дедалі більше сфер життєдіяльності. Освіта України загалом і вища школа, зокрема, не можуть стояти осторонь, поза межами європейської інтеграції. Зона європейської вищої освіти має базуватися на спільних фундаментальних принципах і підходах в організації вищої освіти. Відкрита зона європейської вищої освіти розкриває багато нових позитивних спільних перспектив, і разом 3 тим зберігає повагу до національних особливостей функціонування освіти в кожній окремій країні.

Нинішній етап становлення і реформування системи освіти стосовно входження України до Болонської угоди, відкриває реальні можливості реалізації завдань «Національної доктрини розвитку освіти», у якій пріоритетними напрямами державної політики щодо розвитку освіти $є$ особистісна орієнтація освіти, підвищення якості освіти, оновлення ії змісту та форм організації навчального 
процесу. Стратегічний напрям такого розвитку в умовах інтенсивних змін інформаційного середовища та впровадження новітніх інноваційних технологій навчання, сама практика педагогічної роботи вимагають розробляти і впроваджувати розвивальні освітні системи як об'єктивну потребу суспільства в певному типі освітньої діяльності. Унаслідок цього освітня діяльність у галузі підготовки кваліфікованих працівників відповідно до положень про освітньо-кваліфікацйні рівні (ступеневу освіту), вимагає здійснення навчальної роботи згідно 3 відповідними освітньопрофесійними програмами і державними стандартами, затвердженими Кабінетом Міністрів України, і визначеними критеріями освіти в рамках Болонського процесу.

У навчально-виховній діяльності закладів вищої освіти України впродовж попередніх десятиріч увагу було зосереджено на оволодінні студентами розгалуженою системою знань на екстенсивних засадах організації навчального процесу. За таких умов було складно забезпечити належний рівень інтелектуального розвитку особистості, підготувати ㄲï до самостійної пізнавальної діяльності впродовж життя. Тому нині можливості організації екстенсивної освітньої діяльності вищих навчальних закладів вичерпали себе.

Екстенсивний (від лат. Extensivus - розширювальний) підхід передбачає досягнення результатів у навчанні за рахунок кількісних чинників (збільшення років навчання, кількості годин на опанування певними навчальними дисциплінами тощо).

Розвиток науки, збільшення обсягу інформації, актуалізація проблеми продукування інтелектуального багатства суспільства зумовили необхідність інтенсифікації навчального процесу.

Інтенсифікація (від фр. Intensification - напружено, роблю) передбачає досягнення в навчанні бажаних результатів за рахунок якісних чинників, тобто за рахунок напруження розумових можливостей особистості, оскільки в процесі екстенсивного навчання можливості мозку використовуються на 15-20 \%. Тому збільшення ефективності використання потенційних здатностей мозку студентів та викладачів - це найперша умова інтенсифікації навчального процесу [2].

Також під терміном «інтенсифікація» навчання i творчої навчальної діяльності, зокрема, розуміють:

- досягнення максимальної ефективності в роботі за мінімально можливий навчальний час при мінімальній затраті зусиль того, хто навчається, й учителя (Ю. Бабанський) [4];

- $\quad$ процес переходу навчально-творчої діяльності 3 певного рівня активності на більш високий $і$ ефективний рівень на основі комплексного підходу до оптимізації факторів і умов педагогічного управління та самоуправління студентів, зорієнтованих на максимальне використання резервних можливостей особистості (В. Андреєв) [3, с. 32].

Якщо розглядати професійну підготовку фахівців як процес «виробництва» інтелектуального продукту, то за анало- гією інтенсивність педагогічного процесу можна визначити як повніше й раціональніше використання технічних (засоби навчання), матеріальних (кошти) i трудових (професорсько-викладацький склад) ресурсів, із застосуванням ефективних засобів «виробництва» (методи навчання) та досягнень науково-технічного прогресу.

Поміж шляхів інтенсифікації навчання вчені розглядають побудову навчальної діяльності як організовану, керовану та контрольовану послідовність дій студентів, що забезпечує оптимальне формування навчальної діяльності i iї структурних компонентів (дій і операцій) та пошук оптимального співвідношення свідомих і підсвідомих компонентів у формуванні навчальної діяльності [1, с. $82-83]$.

До головних чинників інтенсифікації процесу навчання студентів у вищому навчальному закладі належать: 1) підвищення цілеспрямованості навчання; 2) посилення мотивування навчання; 3) прискорення темпу навчальних дій; 4) розвиток навичок навчальної праці; 5) активізація процесу навчання; 6) розширення інформаційного змісту навчальних занять; 7) удосконалення організаційних форм навчання; 8) створення проблемних ситуацій; 9) творчий підхід педагога до справи; 10) використання комп'ютерів; 11) використання засобів наочності та аудіовізуальних засобів навчання; 12) використання логіко-пізнавальних прийомів (аналізу, синтезу, індукції, дедукції, узагальнення, порівняння, аналогії, інтерполяції тощо)[8, с. 44].

Також потрібно зважати на фактори, які у своїй єдності і взаємозв'язку забезпечують інтенсивність навчання в таких аспектах:

- організація навчального процесу на достатньому науковому рівні 3 погляду розуміння сутності навчання, його рушійної сили, логіки навчального процесу, методів, засобів, форм, типів;

- забезпечення високого рівня психолого-педагогічної підготовки вчителів;

- оптимальність змісту навчального матеріалу 3 погляду його доступності щодо вікових та індивідуальних можливостей школярів;

- демократизація і гуманістична спрямованість навчально-виховного процесу;

- створення сприятливих санітарно-гігієнічних умов для навчання (харчування, дотримання вимог повітряного, теплового режимів, гігієна розумової праці);

- забезпечення модульно-рейтингової системи оцінювання навчальної діяльності студентів;

- володіння вчителем інноваційними технологіями навчання, педагогічною технікою i психотехнікою; 
- забезпечення високого соціально-економічного статусу вчителя в суспільстві.

Для успішної інтенсифікації навчального процесу слід розробляти і впроваджувати науково обгрунтовані методи керівництва пізнавальним процесом, що мобілізують творчий потенціал особистості. Підвищення темпів навчання може бути досягнуто шляхом вдосконалення змісту навчального матеріалу і методів навчання [7, с. 435].

Удосконалення змісту передбачає:

- раціональний відбір навчального матеріалу з чітким виділенням у ньому основної, базової частини і додаткової, другорядної інформації; відповідним чином має бути укладена основна і додаткова література;

- перерозподіл за часом навчального матеріалу з тенденцією викладу нового навчального матеріалу на початку заняття, коли сприйняття студентів більш активне;

- концентрацію аудиторних занять на початковому етапі освоєння курсу задля засвоєння знаннями, необхідних для плідної самостійної роботи;

- раціональне дозування навчального матеріалу для багаторівневого опрацювання нової інформації з урахуванням того, що процес пізнання розвивається не за лінійним, а за спіральним принципом;

- забезпечення логічної наступності нової і вже засвоєної інформації, активне використання нового матеріалу для повторення і глибшого засвоєння пройденого;

- економне й оптимальне використання кожної хвилини навчального часу [7, с. 441].

Удосконалення методів навчання забезпечується через:

- широке використання колективних форм пізнавальної діяльності (парна і групова робота, рольові та ділові ігри тощо);

- вироблення у викладача відповідних навичок організації управління колективною навчальною діяльністю студентів;

- застосування різних форм та елементів проблемного навчання;

- удосконалення навичок педагогічного спілкування, мобілізуючих творче мислення студентів;

- індивідуалізацію навчання під час роботи у студентській групі та облік особистісних характеристик у розробленні індивідуальних завдань і виборі форм спілкування;

- прагнення до результативності навчання і рівномірного просування всіх студентів у процесі пізнання незалежно від вихідного рівня їх знань та індивідуальних здібностей;

- використання новітніх наукових даних у галузі соціальної та педагогічної психології;

- застосування сучасних аудіовізуальних засобів, ТЗН, а також інформаційних засобів навчання [7, c. 445].

Із поняттям «інтенсифікація навчання» корелює поняття «активізація навчання». Під активізацією навчальної діяльності розуміють цілеспрямовану діяльність викладача, спрямовану на розроблення і використання таких форм, змісту, прийомів і засобів навчання, які сприяють підвищенню інтересу, самостійності, творчої активності студента у засвоєнні знань, формуванні умінь, навичок у їх практичному застосуванні, а також формуванні здібностей прогнозувати виробничу ситуацію i приймати самостійні рішення [5, с. 239].

Нині постає реальна необхідність розроблення і застосування відкритої системи інтенсивного навчання. Ці системи дають студентові змогу вибору відповідної йому технології навчання та розроблення індивідуальної програми формування особистості. Проте реалізація синтезу відкритих систем інтенсивного навчання можлива лише за дотримання низки умов:

- усебічне врахування характеристик педагогічного середовища, у якому буде проходити процес навчання: змістовні характеристики педагогічного середовища визначаються знаннями, вміннями і навичками, пізнавальним і культурним потенціалами, формами і методами організації навчання і самостійної роботи студентів;

- дотримання принципу адаптації процесу навчання до особистості студента; цей принцип реалізується на практиці через нелінійне структурування дисципліни (складання іiі зовнішнього і внутрішнього модулів) і складання розгалуженої програми іiї вивчення студентами;

- прискорення індивідуального засвоєння студентами загальнонаукових і спеціальних знань завдяки проектуванню «логічного конструкту» дисципліни, у якому подано базові знання в згорнутому вигляді [7, с. 454].

Інтенсифікація навчання як передачає більший обсяг навчальної інформації студентів за незмінної тривалості навчання без зниження вимог до якості знань вважається одним з перспективних напрямів активізації навчальної діяльності. Процеси інтенсифікації грунтуються на взаємодії індивідуальнопсихологічних та колективно-психологічних факторів у навчальній діяльності.

Таким чином, традиційна технологія навчання (від знання до умінь) може і повинна бути доповнена новими інтенсивними технологіями, заснованими на закономірностях пізнавальної діяльності. Поняття «інтенсивні технології навчання» можна розуміти як сукупність принципів, етапів, способів, інструментів і систем послідовного управління процесами навчання 3 метою передачі більшого обсягу навчальної інформації студентів при незмінній тривалості навчання без 
зниження вимог до якості знань. Інтенсивні технології навчання повинні мобілізувати пізнавальний $\mathrm{i}$ творчий потенціал особистості, яка навчається.

Забезпечення інтенсифікації навчання - проблема досить складна. Вона виходить далеко за межі суто педагогічних проблем, однак об'єктивні чинники соціально-економічного розвитку підносять іiі актуальність.

На сучасному етапі соціально-економічного розвитку України інтенсифікація навчального процесу стає актуальною проблемою професійної підготовки студентів. Ї̈ розв'язання спрямоване на задоволення потреб суспільства в активних і творчих спеціалістах, які мали б грунтовну теоретичну та практичну підготовку 3 обраного фаху, могли самостійно приймати рішення, пов'язані 3 професійною діяльністю, щоб цілеспрямовано створювати інтелектуальні й матеріальні цінності в майбутньому. Молодий спеціаліст має чітко усвідомлювати, що з отриманням диплома процес його професійної зрілості не закінчується. Починається серйозна самостійна робота 3 постійного оновлення своїх знань, швидкого адаптування до нових умов професійної діяльності.

Перспективи подальших пошуків у напрямку дослідження вбачаємо в з'ясуванні методів інтенсифікації процесу навчання студентів у вищому навчальному закладі.

\section{Література}

1. Азимов Э. Г. Новый словарь методических терминов и понятий (теория и практика обучения языкам)/ Э. Г. Азимов, А. Н. Щукин. - М. : ЗАО «Издательство ИКАР», 2009. - 448 с. 2. Алексюк А. М. Педагогіка вищої освіти України. Історія. Теорія : [підручник для студ., аспірантів ] / А. М. Алексюк. - К., 1998. 3. Андреев В. И. Диалектика воспитания и самовоспитания творческой личности: основы педагогики творчества / В. И. Андреев. - Казань : Изд-во Казанского ун-та, 1988. - 238 с. 4. Бабанский Ю. К. Оптимизация учебно-воспитательного процесса: (Методические основы) / Ю. К. Бабанский. - М. : Просвещение, 1982. 192 с. 5. Педагогика / под ред. П. И. Пидкасистого. - М. : Пед. общество России, 1998. - 640 с. 6. Повышение эффективности педагогических дисциплин в высшей школе / под ред. Ю. К. Бабанского. - М., 1976. - 144 с. 7. Столяренко Л. Д. Психология и педагогика в вопросах и ответах / Л. Д. Столяренко, С. И. Самигин. Ростов-на-Дону : Феникс, 2000. - 576 с. 8. Щербань П. М. Прикладна педагогіка : [навч.-метод. посібн.] / П. М. Щербань. - К., 2002. 9. Фіцула М. М. Педагогіка вищої школи : [навч. посібн.] / М. М. Фіцула. - К. : Академвидав, 2006. - $352 \mathrm{c}$. 